\title{
Hubungan Pemakaian Panty Liner dengan Kejadian Fluor Albus pada Siswi SMA di Kota Padang Berdasarkan Wawancara Terpimpin (Kuisioner)
}

\author{
Anisa Persia ${ }^{1}$, Rina Gustia ${ }^{2}$, Elizabeth Bahar $^{3}$
}

\begin{abstract}
Abstrak
Penyebab tersering fluor albus (keputihan) patologis adalah infeksi. Proses infeksi dapat dipicu oleh banyak hal, salah satunya adalah karena pemakaian panty liner. Tujuan penelitian ini adalah menentukan hubungan antara pemakaian panty liner dengan kejadian fluor albus pada siswi SMA. Penelitian dilakukan pada siswi di enam SMA di kota Padang. Penelitian ini menggunakan desain cross sectional study dengan responden sebanyak 289 orang. Pengumpulan data responden dilakukan dengan wawancara terpimpin (pengisian kuisioner). Analisis statistik yang digunakan adalah uji chi-square. Hasil penelitian didapatkan bahwa lebih dari separuh responden yang memakai panty liner mengalami fluor albus $(69,2 \%)$ dan $80 \%$ diantaranya mengganti panty liner <2 kali perhari. Uji statistik chisquare menunjukkan ada hubungan yang bermakna antara pemakaian panty liner dengan kejadian fluor albus $(p<0,05)$ dan frekuensi penggantian panty liner perhari dengan kejadian fluor albus $(p<0,05)$. Terdapat hubungan bermakna antara pemakaian panty liner dengan fluor albus pada siswi SMA di Kota Padang.
\end{abstract}

Kata kunci: fluor albus, panty liner, siswi SMA

\section{Abstract}

The most common of pathology fluor albus is infection. Infection can be cocked by panty liner uses. The objective of this study was to determine relationship between panty liner uses and the incidence of fluor albus in female student of Senior High School. The research was executed to female student of senior high school in Padang. There are six schoos/ was chosen as sample. This research used cross sectional study design to 289 respondent. Data was collected by guided interview. Statistic analysis use chi-square test. The result of research found more than half respondent who use panty liner experience of fluor albus (69.2\%) and $80 \%$ of them just replace panty liner $<2$ times a day. Chi-square test showed that there is significant relationship between panty liner uses with fluor albus experience $(p<0.05)$ and frequency of panty liner uses replacement with fluor albus experience $(p<0.05)$. There is a significant relationship between panty liner uses and the incidence of fluor albus in female student of senior high school at Padang.

Keywords: fluor albus, panty liner, female student of senior high school

Affiliasi penulis: 1. Pendidikan dokter FK UNAND (Fakultas Kedokteran Universitas Andalas Padang), 2. Bagian IImu Penyakit Kulit dan Kelamin FK UNAND, 3. Bagian Mikrobiologi FK UNAND

Korespondensi: Anisa Persia, E-mail: persia.anisa@gmail.com, Telp: 082387421962

\section{PENDAHULUAN}

Fluor albus (keputihan, leukorea, vaginal discharge) merupakan istilah yang digunakan untuk cairan yang keluar dari genitalia wanita yang bukan berupa darah. ${ }^{1}$ Fluor albus adalah gejala yang sering ditemukan pada pasien ginekologi. Sepertiga pasien ginekologi datang dengan keluhan fluor albus. Fluor albus menjadi salah satu dari 25 alasan terbanyak untuk mengunjungi tenaga medis di Amerika Serikat. ${ }^{2}$

Menurut data penelitian tentang kesehatan reproduksi menyatakan bahwa $75 \%$ wanita di dunia 
pernah mengalami fluor albus paling tidak sekali dalam hidup dan $45 \%$ diantaranya mengalami fluor albus 2 kali atau lebih. Di Indonesia, terdapat peningkatan angka kejadian fluor albus. Pada tahun 2002, 50\% wanita di Indonesia pernah mengalami fluor albus.Tahun 2003 angka tersebut naik menjadi $60 \%$ dan tahun 2004 menjadi $70 \%{ }^{3}$

Pemakaian panty liner merupakan salah satu faktor predisposisi timbulnya keputihan. Panty liner (pantliner, panty shield) merupakan salah satu jenis pembalut wanita yang digunakan pada saat diluar periode menstruasi. Panty liner memiliki susunan yang sama dengan pembalut ketika menstruasi namun ukurannya lebih tipis. Pemakaian panty liner bertujuan untuk menyerap cairan vagina, keringat, bercak darah, sisa darah menstruasi dan terkadang juga dipakai sebagai penyerap urin bagi wanita inkontinensia. ${ }^{4}$

Kulit vulva memiliki perbedaan dengan kulit lengan bawah pada lapisan sratum corneum. Kulit vulva akan mengalami peningkatan hidrasi apabila terjadi gesekan pada permukaanya dan keadaan ini tidak ditemukan pada kulit lengan bawah. ${ }^{5}$

Berdasarkan penelitian Farage, panty liner meningkatkan populasi Eubacterium species di vagina dan menurunkan jumlah Lactobacillus species di vagina sebagai flora normal. Pemakaian panty liner juga dapat mentransfer flora intestinal seperti Eschericia coli ke dalam vagina dan pemakaian panty liner non breathable dapat meningkatkan risiko Kandidiasis. ${ }^{4}$

Laporan dermatitis kontak alergi akibat pemakaian panty liner tetap ada. Biasanya masalah alergi tersebut terkait dengan dermatosis vulva, infeksi vulva dan akibat hipersensitifitas terhadap parfum, bahan perekat maupun bahan penyusun lainnya pada panty liner. 6

Penelitian ini bertujuan untuk mengetahui hubungan antara pemakaian panty liner dengan kejadian fluor albus pada siswi SMA di kota Padang.

\section{METODE}

Penelitian ini akan dilaksanakan di enam SMA di kota Padang, yakni SMA N 3, SMA N 10, SMA N 6, SMA N 4, SMA Adabiah dan SMA PGRI 1 dengan total sampel sebanyak 298 orang Penelitian ini dilakukan sejak Oktober 2011-Januari 2013.

Responden adalah siswi SMA yang telah memenuhi kriteria inklusi dan tidak terdapat kriteria eksklusi. Data yang diperoleh diolah secara komputerisasi, dan untuk analisis hasil penelitiannya digunakan uji chi-square dengan tingkat pemaknaan $p<0,05$.

\section{HASIL DAN PEMBAHASAN}

Tabel 1. Distribusi frekuensi pemakaian panty liner pada siswi SMA di kota Padang

Pemakaian Panty liner Jumlah Siswi Persentase (\%)

\begin{tabular}{ccc}
\hline Tidak & 237 & 82.0 \\
Ya & 52 & 18.0 \\
& & \\
\hline Total & 289 & 100.0 \\
\hline
\end{tabular}

Tabel 1 menunjukkan pemakaian panty liner pada siswi dari enam SMA yang mewakili siswi SMA Kota Padang. Terlihat 18\% siswi memakai panty liner, sedangkan $82 \%$ tidak memakai panty liner.

Penelitian mengenai prevalensi wanita yang memakai panty liner belum banyak dilakukan, sehingga berdasarkan data yang diperoleh, dapat disimpulkan bahwa kurang dari $20 \%$ siswi SMA di Kota Padang yang memakai panty liner.

Tabel 2. Distribusi frekuensi penggantian pantyliner per hari pada siswi SMA di kota Padang

\begin{tabular}{cccccc}
\hline \multicolumn{3}{c}{ Frekuensi Penggantian Panty liner per hari } \\
\hline \multicolumn{2}{c}{$<$ 2 kali } & \multicolumn{2}{c}{$>$ 2 kali } & \multicolumn{2}{c}{ Total } \\
\hline $\mathrm{f}$ & $\%$ & $\mathrm{f}$ & $\%$ & $\mathrm{f}$ & $\%$ \\
\hline 30 & 57,7 & 22 & 42,3 & 52 & 100 \\
\hline
\end{tabular}

Tabel 2 menunjukkan bahwa 57,7\% dari siswi SMA pemakai panty liner di Kota Padang yang diwakili dari enam SMA, mengganti panty liner kurang dari 2 kali per hari, $42,3 \%$ nya mengganti panty liner $2-4$ kali sehari.

Penelitian mengenai frekuensi penggantian panty liner pada wanita yang menggunakan panty liner belum banyak dilakukan, tetapi dari data yang penulis dapatkan dapat disimpulkan bahwa lebih dari 50\% 
siswi SMA yang memakai panty liner, mengganti panty liner $<2$ kali perhari.

Tabel 3. Distribusi frekuensi kejadian fluor albus pada siswi SMA di kota Padang

\begin{tabular}{ccc}
\hline $\begin{array}{c}\text { Diagnosa Fluor albus } \\
\text { Berdasarkan Kuisioner }\end{array}$ & $\mathbf{f}$ & $\%$ \\
\hline $\begin{array}{c}\text { Tidak Fluor albus } \\
\text { Fluor albus }\end{array}$ & 185 & 64.0 \\
\hline Total & 104 & 36.0 \\
\hline
\end{tabular}

Pada Tabel 3 dapat dilihat bahwa 36\% siswi SMA di Kota padang, yang diwakili enam SMA mengalami fluor albus. Sedangkan $64 \%$ nya tidak mengalami fluor albus.

Hasil ini sesuai dengan pernyataan Sobel (2004) bahwa hanya sekitar $20 \%$ wanita yang mengalami fluor albus patologis. ${ }^{2}$

Tabel 4. Hubungan pemakaian panty liner dengan kejadian fluor albus pada siswi SMA di kota Padang.

\begin{tabular}{|c|c|c|c|c|c|c|}
\hline \multirow[t]{3}{*}{$\begin{array}{l}\text { Pemakaian } \\
\text { Panty liner }\end{array}$} & \multicolumn{4}{|c|}{$\begin{array}{l}\text { Diagnosa fluor albus } \\
\text { Melalui Kuisioner }\end{array}$} & \multicolumn{2}{|c|}{ Total } \\
\hline & \multicolumn{2}{|c|}{$\begin{array}{l}\text { Fluor } \\
\text { albus }\end{array}$} & \multicolumn{2}{|c|}{$\begin{array}{l}\text { Tidak fluor } \\
\text { albus }\end{array}$} & & \\
\hline & $f$ & $\%$ & $f$ & $\%$ & $f$ & $\%$ \\
\hline $\mathrm{Ya}$ & 36 & 69,2 & 16 & 30,8 & 52 & 100 \\
\hline Tidak & 68 & 28,7 & 169 & 71,3 & 237 & 100 \\
\hline Total & 104 & 36 & 185 & 64 & 289 & 100 \\
\hline
\end{tabular}

Dari Tabel 4 terlihat bahwa fluor albus lebih banyak terjadi pada responden yang memakai panty liner (69,2\%). Jika dibandingkan dengan responden yang tidak memakai panty liner $(28,7 \%)$. Berdasarkan uji statistik yang diperoleh, nilai $p=0,000$. Dapat disimpulkan bahwa terdapat hubungan yang bermakna antara pemakaian panty liner dengan kejadian fluor albus pada siswi SMA di Kota Padang. $\mathrm{Hal}$ ini sejalan dengan penelitian yang dilakukan oleh Runeman et al tahun 2003 bahwa pemakaian panty liner akan meningkatkan suhu $1,5^{\circ} \mathrm{C}$, peningkatan kelembapan, dan peningkatan $\mathrm{pH}$ sebesar 0,6 di area vulva dan perineum. Keadaan ini akan meningkatkan kemungkinan terjadinya pertumbuhan kuman dan jamur patogen penyebab fluor albus. ${ }^{3}$

Penelitian yang dilakukan oleh Farage tahun
1997 mendapatkan bahwa pemakaian panty liner menurunkan jumlah Lactobacillus species di vagina sebagai flora normal, sehingga akan memacu pertumbuhan organisme penyebab fluor albus. ${ }^{4}$

Tabel 5. Hubungan frekuensi penggantian panty liner dengan kejadian fluor albus

\begin{tabular}{ccccccc}
\hline $\begin{array}{c}\text { Frekuensi } \\
\text { Penggantia } \\
\text { n Panty } \\
\text { liner Per } \\
\text { hari }\end{array}$ & \multicolumn{4}{c}{$\begin{array}{c}\text { Diagnosa fluor albus } \\
\text { Melalui Kuisioner }\end{array}$} & \multirow{2}{*}{ Total } \\
\cline { 2 - 5 } & Fluor albus & $\begin{array}{c}\text { Tidak fluor } \\
\text { albus }\end{array}$ & \\
\cline { 2 - 6 } & $\mathbf{f}$ & $\%$ & $\mathbf{f}$ & $\%$ & $\mathbf{f}$ & $\%$ \\
\hline$<2$ kali & 24 & 80 & 6 & 20 & 30 & 100 \\
$2-4$ kali & 10 & 54,5 & 9 & 45,5 & 22 & 100 \\
\hline
\end{tabular}

Tabel 5 menunjukkan responden yang mengalami fluor albus pada pemakai panty liner lebih banyak pada pada responden yang mengganti panty liner kecil dari 2 kali per hari, dengan persentase sebesar $80 \%$ jika dibandingkan dengan responden yang mengganti panty liner sebanyak 2-4 kali per hari yaitu dengan persentase $52,6 \%$. Berdasarkan uji statistik yang diperoleh, nilai $p=0,000$. Dapat disimpulkan bahwa terdapat hubungan yang bermakna anatara frekuensi penggantian panty liner dengan kejadian fluor albus pada siswi SMA di Kota Padang.

Penelitian sebelumnya mengenai frekuensi penggatian panty liner dengan kejadian fluor albus memang belum banyak dilakukan tetapi hasil penelitian ini sejalan dengan pendapat ahli bahwa pemakaian panty liner dengan frekuensi penggantian yang minimal setiap harinya akan lebih memungkinkan terjadinya fluor albus karena peningkatan suhu, kelembapan, dan $\mathrm{pH}$ yang lebih lama memberikan waktu yang lebih potensial dan memungkinkan untuk mikroorganisme penyebab fluor albus berkembang biak. $^{3}$

\section{KESIMPULAN}

Kejadian fluor albus pada responden yang memakai panty liner lebih tinggi dibandingkan dengan responden yang tidak memakai panty liner.

Terdapat hubungan bermakna antara 
pemakaian panty liner dengan kejadian fluor albus.

Terdapat hubungan bermakna antara frekuensi penggantian panty liner perhari dengan kejadian fluor albus.

\section{DAFTAR PUSTAKA}

1. Zubier F. Fluor Albus pada bayi dan anak. Dalam: Serba Serbi Penyakit Kulit dan Kelamin Sejak Neonatal Sampai Geriatri. KSDAI. Jakarta: Balai Penerbit FKUI. 2009.hIm.22-4

2. Sobel J. Vaginitis. Obstetric and Gynecology Emergencies. New York; McGraw Hill Medical Publishing Division. 2004.
3. Runeman B. The vulva skin microclimate: influence of panty liner on temperature, humidity, and $\mathrm{pH}$. Act Derm Venerol. 2003;83: 88-92.

4. Farage M. Labial And vaginal microbiology : effects of extended panty liner use. Infectious Disease in Obstetric and Gynecology. 1997;5:252-8.

5. Prawirohardjo S. Infeksi genitalia. Dalam: Buku Ajar Ginekologi. Jakarta: Balai Penerbit FKUI. 2007. hlm.123-9.

6. Fahmi S. Perawatan genitalia sejak neonatal sampai geriatri. Dalam: Serba Serbi Penyakit Kulit dan Kelamin. KSDAI. Jakarta: Balai Penerbit FKUI. 2009. hlm.35-7. 